\title{
Expression of urease by Haemophilus influenzae during human respiratory tract infection and role in survival in an acid environment
}

Timothy F Murphy ${ }^{1,2,3^{*}}$ and Aimee L Brauer ${ }^{1,3}$

\begin{abstract}
Background: Nontypeable Haemophilus influenzae is a common cause of otitis media in children and lower respiratory tract infection in adults with chronic obstructive pulmonary disease (COPD). Prior studies have shown that $H$. influenzae expresses abundant urease during growth in the middle ear of the chinchilla and in pooled human sputum, suggesting that expression of urease is important for colonization and infection in the hostile environments of the middle ear and in the airways in adults. Virtually nothing else is known about the urease of $H$. influenzae, which was characterized in the present study.

Results: Analysis by reverse transcriptase PCR revealed that the ure gene cluster is expressed as a single transcript. Knockout mutants of a urease structural gene (ureC) and of the entire ure operon demonstrated no detectable urease activity indicating that this operon is the only one encoding an active urease. The ure operon is present in all strains tested, including clinical isolates from otitis media and COPD. Urease activity decreased as nitrogen availability increased. To test the hypothesis that urease is expressed during human infection, purified recombinant urease $C$ was used in ELISA with pre acquisition and post infection serum from adults with COPD who experienced infections caused by $\mathrm{H}$. influenzae. A total of $28 \%$ of patients developed new antibodies following infection indicating that $H$. influenzae expresses urease during airway infection. Bacterial viability assays performed at varying $\mathrm{pH}$ indicate that urease mediates survival of $\mathrm{H}$. influenzae in an acid environment.

Conclusions: The $\mathrm{H}$. influenzae genome contains a single urease operon that mediates urease expression and that is present in all clinical isolates tested. Nitrogen availability is a determinant of urease expression. H. influenzae expresses urease during human respiratory tract infection and urease is a target of the human antibody response. Expression of urease enhances viability in an acid environment. Taken together, these observations suggest that urease is important for survival and replication of $H$. influenzae in the human respiratory tract.
\end{abstract}

\section{Background}

Nontypeable (non encapsulated) Haemophilus influenzae is an exclusively human pathogen whose primary ecological niche is the human respiratory tract. $H$. influenzae is a common and important human pathogen, causing otitis media in children and lower respiratory tract infection in adults with chronic obstructive pulmonary disease (COPD) [1-3]. The course of COPD, the fourth leading cause of death in the world, is characterized by intermittent worsening called exacerbations.

\footnotetext{
* Correspondence: murphyt@buffalo.edu

'Division of Infectious Diseases, Department of Medicine, 701 Ellicott Street, University at Buffalo, State University of New York, Buffalo, NY 14203, USA Full list of author information is available at the end of the article

Approximately half of exacerbations are caused by bacterial infection, with $H$. influenzae being the most frequent bacterial cause [2]. In addition to causing exacerbations, $H$. influenzae also chronically colonizes the lower airways of adults with COPD. The normal human respiratory tract is sterile below the vocal cords, as determined by culture. However, in adults with COPD, the lower airways are colonized by bacteria, with H. influenzae as the most common pathogen in this setting [4-7].

The human respiratory tract is a hostile environment for bacteria. Nutrients and energy sources are limited. In the setting of COPD, airways are characterized by an oxidant/antioxidant imbalance and by an inflammatory 
milieu [8-12]. Thus to survive and cause infection in the human respiratory tract, $H$. influenzae must express proteins and other molecules to enable persistence in this unique environment.

In previous work, we characterized the proteome of $H$. influenzae that was grown in pooled human sputum obtained from adults with COPD in an effort to simulate the environment of the human airways in COPD [13]. In comparison to the same strain of $H$. influenzae grown in chemically defined media, 31 proteins were present in greater abundance in sputum grown-conditions at a ratio of $>1.5$ compared to media-grown conditions. These included antioxidant proteins, stress response proteins, proteins that function in the uptake of divalent cations and proteins that function in the uptake of various molecules. Interestingly, the second most abundant protein with regard to the ratio of sputum-grown to media-grown analysis was urease $C$, the alpha subunit of urease, which was present in an abundance of 7 -fold greater in sputum-grown conditions compared to media-grown conditions. This is an interesting finding in light of the observation by Mason et al [14] who monitored gene expression by $H$. influenzae in the middle ear of a chinchilla, the most widely used animal model of otitis media. The gene that encodes urease accessory protein, $\mathrm{ureH}$, was induced 3.9-fold in bacterial cells in the middle ear compared to baseline. These two genes, ure $C$ and $u r e H$ are part of the urease gene cluster and were among the most highly up regulated genes. These observations suggest that expression of urease is important for survival and growth of $H$. influenzae in the respiratory tract.

Ureases are nickel dependent enzymes that catalyze the hydrolysis of urea to form ammonia and carbon dioxide $[15,16]$. Urease is best studied as a virulence factor in Helicobacter pylori which colonizes the stomach and Proteus mirabilis which causes urinary tract infections [17-23]. Urease is also important for survival and pathogenesis of several bacterial species [24-27]. Urease functions to raise the $\mathrm{pH}$ of the environment, allowing survival in acidic media; urease also enables bacteria to use urea as a sole nitrogen source [28]. While these are the best known functions of urease, this protein also interacts with the human host and acts as virulence factor by several other mechanisms, including activation of macrophages [29], induction of inflammatory mediators [30-32], dysregulation of gastric epithelial tight junctions [33], apoptosis [34], activation of platelets, enhanced survival in macrophages $[35,36]$ and others $[37,38]$.

Virtually nothing is known about the urease of $H$. influenzae. In view of the high degree of up regulation of urease expression by $H$. influenzae in the respiratory tract and the importance of urease as a virulence factor in other bacteria, the goal of this study is to characterize the urease of $H$. influenzae. In particular we have constructed knockout mutants of ure $C$ and the urease operon to assess urease activity by $H$. influenzae, characterized the urease transcript, determined the optimal $\mathrm{pH}$ for urease activity and demonstrated that the urease operon is present in clinical isolates from otitis media and COPD. Analysis of pre and post infection serum samples from adults with exacerbations of COPD caused by $H$. influenzae demonstrated directly that urease is expressed during human infection. Finally, we demonstrate that urease activity enhances survival of $H$. influenzae at a reduced $\mathrm{pH}$.

\section{Results}

\section{Identification of urease gene cluster}

The $\alpha$ subunit of urease, which was present in increased abundance in $H$. influenzae grown in pooled human sputum based on proteomic analysis, is a protein of 572 amino acids with a predicted molecular mass of 62 kilodaltons that is encoded by ure $C$ [13]. The ure $C$ gene is the third gene in the urease gene cluster, (Figure 1A); ure $A$ and $u r e B$ encode the $\gamma$ and $\beta$ subunits respectively and ureE, ureF, ure $G$ and $u r e H$ encode urease accessory proteins. These genes correspond to loci HI0535 through HI0541 in H. influenzae strain KW20 Rd (GenBank L42023.1) and to loci NTHI 0661 through NTHI 0667 in $H$. influenzae strain 86-028NP (GenBank CP000057).

\section{Characterization of mutants}

A ure C mutant was constructed in our prototype COPD exacerbation strain $11 \mathrm{P} 6 \mathrm{H}$ by replacing the ure $C$ gene with a non polar kanamycin resistance cassette by homologous recombination using overlap extension PCR (Figure 1B). The mutant construct was confirmed by PCR using oligonucleotide primers in and around the gene in the wild type strain and the kanamycin cassette in the mutant, and by sequencing through the region of homologous recombination. An immunoblot assay of whole cell lysates probed with rabbit antiserum raised to recombinant urease $C$ reveals the presence of an $\sim 62 \mathrm{kDa}$ protein band in the wild type strain, corresponding to urease $\mathrm{C}$, and no bands in the ureC mutant (Figure 2).

Complementation of the ureC mutation was accomplished by cloning a fragment corresponding to the promoter region of the urease operon upstream of ure $A$ through ure $C$ into plasmid pSPEC and transforming the plasmid into the ure C mutant [39]. The complemented mutant expresses urease $\mathrm{C}$ detected by specific antiserum (Figure 2, lane d).

A knockout of the entire urease gene cluster was constructed using a similar overlap extension PCR strategy (Figure 1C). The mutant construct was confirmed by PCR and sequencing through the region of homologous 


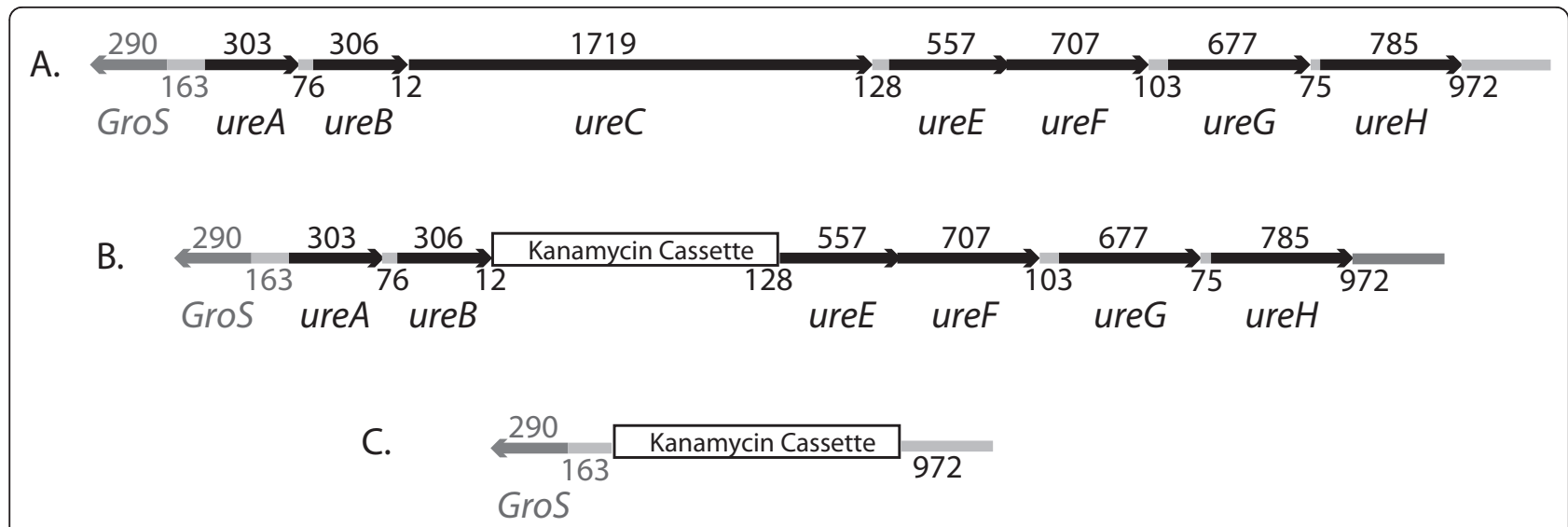

Figure 1 1A. Diagram of urease gene cluster. Numbers above genes indicate length of genes in nucleotides and numbers below indicate nucleotides between gene coding sequences. 1B. Diagram of ureC knockout mutant. 1C. Diagram of urease operon knockout mutant.

recombination. An immunoblot assay of the whole bacterial cell lysate of the urease operon mutant probed with antiserum to urease $C$ reveals an absence of a urease $\mathrm{C}$ band (Figure 2, lane $\mathrm{c}$ ) that is present in wild type.

To further characterize the urease operon mutant, genomic DNA from wild type and urease operon mutant strains was purified, restricted with EcoR1 and subjected to Southern blot assay. Probes that corresponded to the amino terminal region (ureA), the

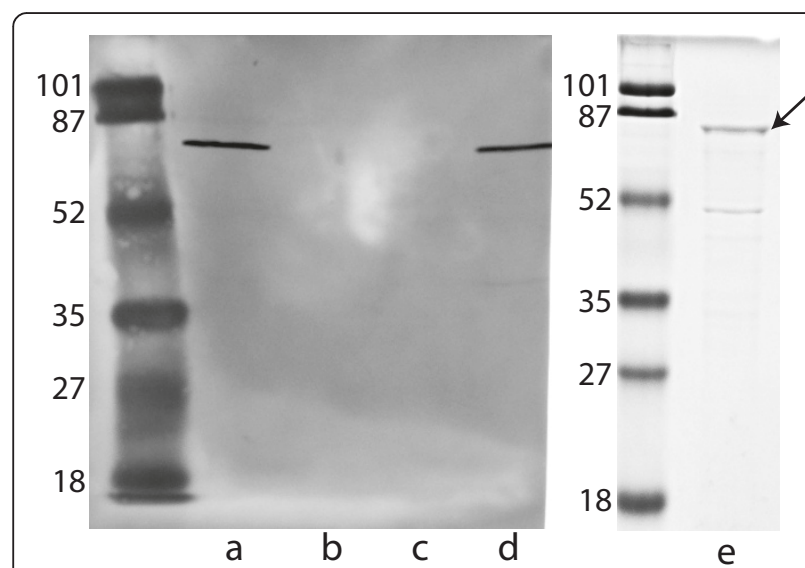

Figure 2 Characterization of mutants and recombinant urease C protein. Left panel. Immunoblot assay probed with rabbit antiserum (1:50,000) raised to recombinant purified urease $C$ and adsorbed with urease mutant $11 \mathrm{P} 6 \mathrm{HureC}$. Blots were probed with goat anti-rabbit lgG (1:1000) and color was developed with horseradish peroxide developer. Lanes contain whole cell lysates as follows: a) Wild type 11P6H; b) Urease ( mutant 11P6HureC; c) Urease operon mutant 11P6Hure; d) Complemented urease $\mathrm{C}$ mutant 11P6HureC (pureC). Right panel. Coomassie blue stained polyacrylamide gel. Lane e) Purified recombinant urease C. Arrow denotes full size protein. The lower band is a fragment of the full size protein. Molecular mass standards are noted on the left of each panel in kilodaltons. central region (ureC) and the carboxy terminal region (ureH) of the gene cluster and the kanamycin cassette revealed an absence of each of these 3 genes in the mutant and the presence of a kanamycin cassette as expected (Figure 3).

\section{Characterization of purified recombinant urease $C$}

Recombinant urease $\mathrm{C}$ was purified by elution from a metal affinity column and refolded by sequential dialysis in buffers that contained decreasing concentrations of arginine. Analysis of the purified protein by SDS PAGE

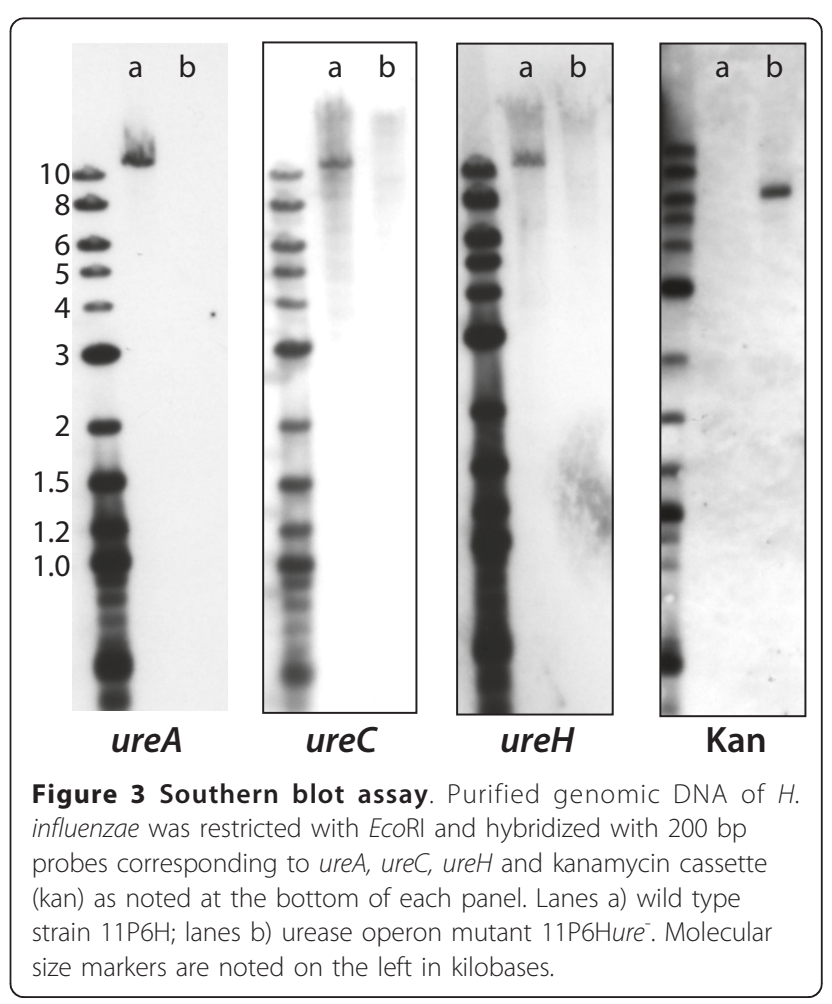


showed a prominent band at the predicted size (Figure 2 , lane e). Preparations of the purified protein also revealed a second band of varying intensity of a lower molecular mass. Immunoblot assay with antibody that recognizes the 6 histidine tag detected both bands, indicating that the smaller band resulted from proteolytic degradation of the full length protein (data not shown). Protease inhibitors were used during purification and storage; however the purified protein was prone to proteolytic degradation. The purified recombinant protein was used to raise antiserum in rabbits and to measure antibody by ELISA in human serum. Thus, this level of proteolytic degradation would not be expected to adversely affect these experiments.

\section{Characterization of urease activity}

Crude cell extracts of $H$. influenzae $11 \mathrm{P} 6 \mathrm{H}$ were used to determine urease activity in wild type $11 \mathrm{P} 6 \mathrm{H}$ and mutant strains. The ure $C$ knockout mutant and the urease operon mutant both demonstrated no detectable urease activity compared to wild type and ure C complemented mutant when grown in laboratory media (Figure 4). We conclude that the ure $A-H$ gene cluster accounts for all detectable urease activity of $H$. influenzae under the conditions of this assay. In addition, knocking out ure $C$ alone, which encodes the major structural subunit of urease, completely abrogates urease activity.

The optimal $\mathrm{pH}$ of $H$. influenzae urease was determined by preparing whole cell extracts in phosphate buffers ranging in $\mathrm{pH}$ from 4 to 8 . The optimal $\mathrm{pH}$ for urease was 7 , with marked reduction in activity at lower $\mathrm{pH}$ (Figure 5).

To begin to assess factors that control urease expression in $H$. influenzae, the effect of nitrogen availability

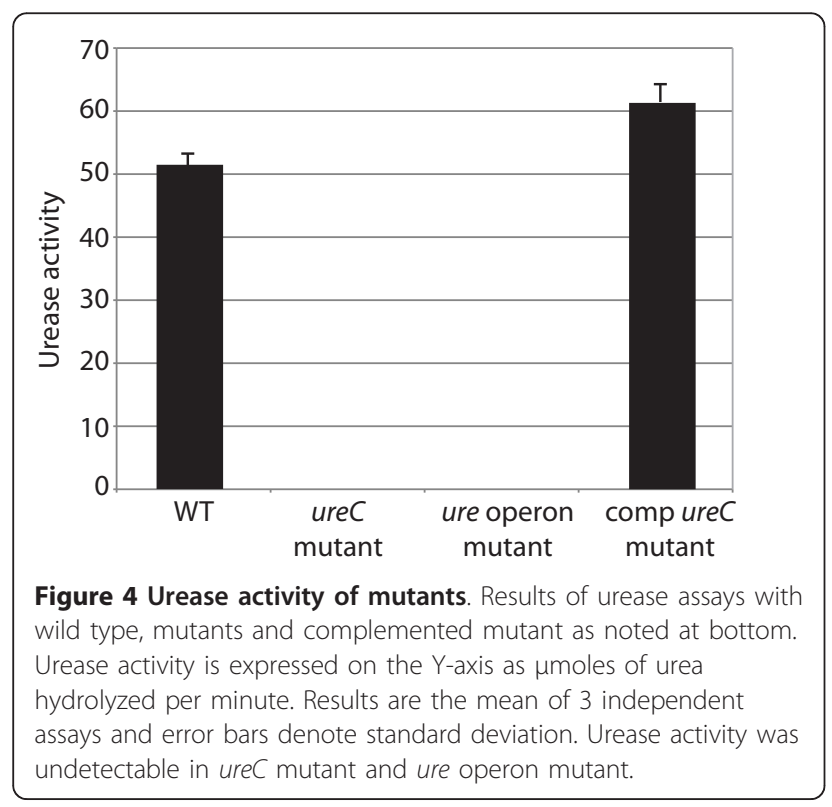

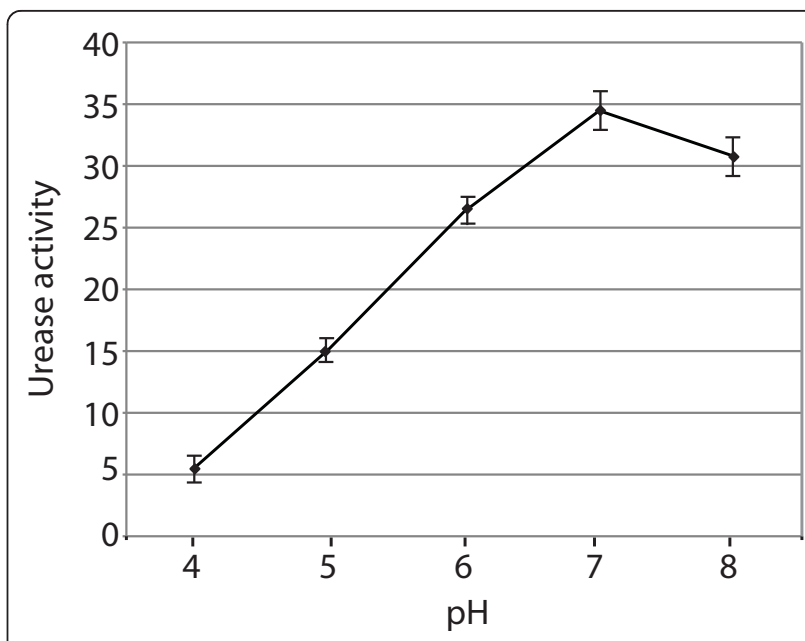

Figure 5 Optimal pH of urease activity. Urease activities of $H$. influenzae protein extracts were assayed in buffers of varying $\mathrm{pH}$ as noted on $\mathrm{X}$-axis. Y-axis is urease activity in $\mu$ mols of urea hydrolyzed per min. Each point is the average of 3 independent experiments and error bars indicate standard deviations.

on urease production was measured by adding increasing concentrations of ammonium chloride to bacteria growing in broth culture. Urease production decreased as the concentration of added ammonium chloride increased (Figure 6).

\section{Analysis of urease transcript}

Reverse transcriptase PCR was performed to determine whether genes ureA through ureH of the urease gene cluster are transcribed as a single transcript or as

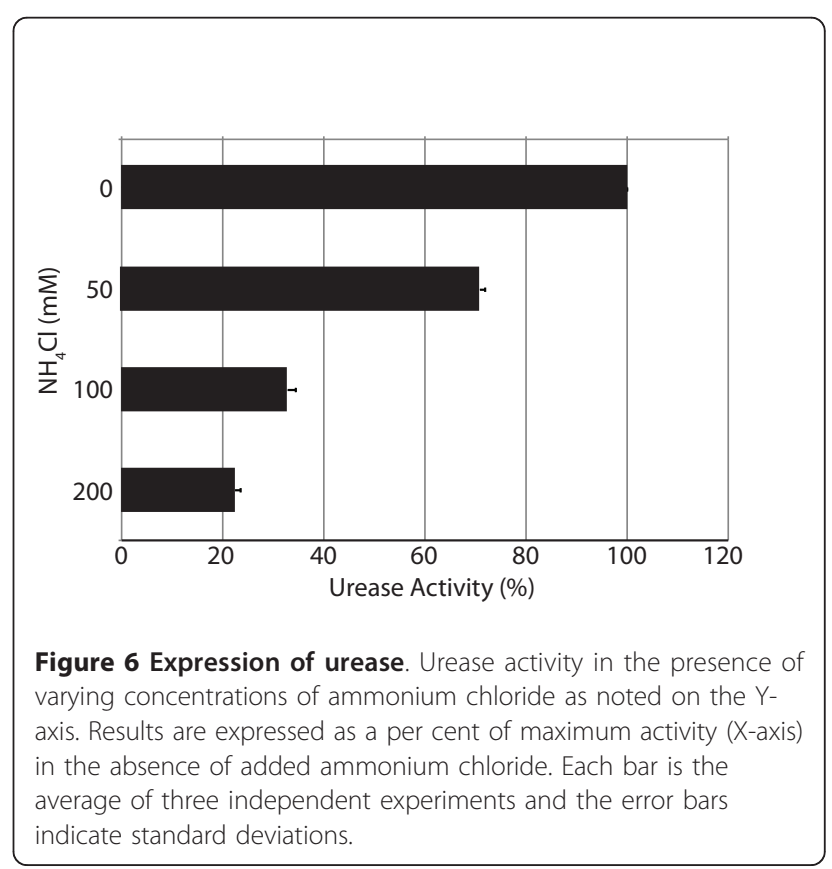


multiple transcripts. Reverse transcriptase PCR was performed using RNA isolated from $H$. influenzae $11 \mathrm{P} 6 \mathrm{H}$ grown in broth using primers designed to correspond to transcripts that would span adjacent genes in the gene cluster (Figure 1). Figure 7 shows that the genes of the urease gene cluster are transcribed as a single transcript. Control assays confirmed that the purified RNA was free of contaminating DNA (Figure 7, lanes b).

\section{Presence of urease operon in clinical isolates}

To determine whether the urease operon is present in clinical isolates of $H$ influenzae, 20 clinical isolates, including 10 otitis media strains and 10 COPD strains were studied by PCR. Primers corresponding to genes located in the 5 region (ureA), central region (ureC) and 3' region (ureH) of the operon were designed. Amplicons of identical size were obtained from 20 of 20 clinical isolates with all 3 sets of primers (Figure 8 ). These results indicate that the urease operon is present in all strains tested and that no variation was observed in the lengths of these genes in diverse strains tested.

A BLASTn search with the sequence corresponding to the urease operon was performed to determine which strains of $H$. influenzae whose genomes are available in GenBank contained the urease operon. Five of 6 strains whose complete genome has been sequenced contain the urease operon. A high degree of sequence similarity in the urease operon is present among the 5 strains. In strain R2866, which is urease negative, the urease operon is replaced by a single gene with homology to the gonococcal $m t r F$ gene [40]. Sequence analysis of the same region of 9 additional urease negative strains revealed sequence that is very similar to that of strain R2866 [40].

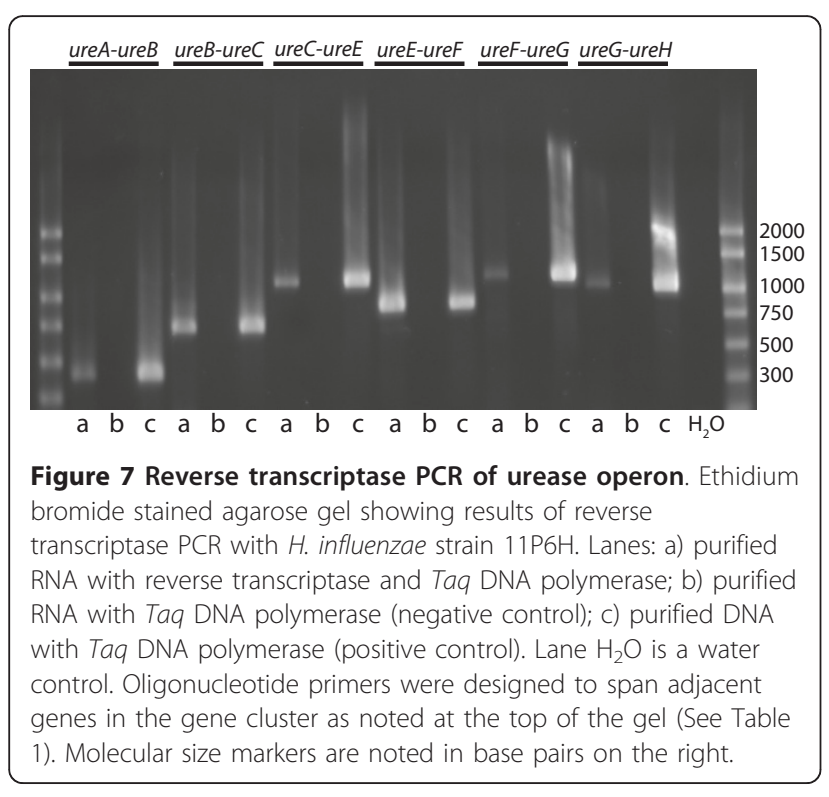

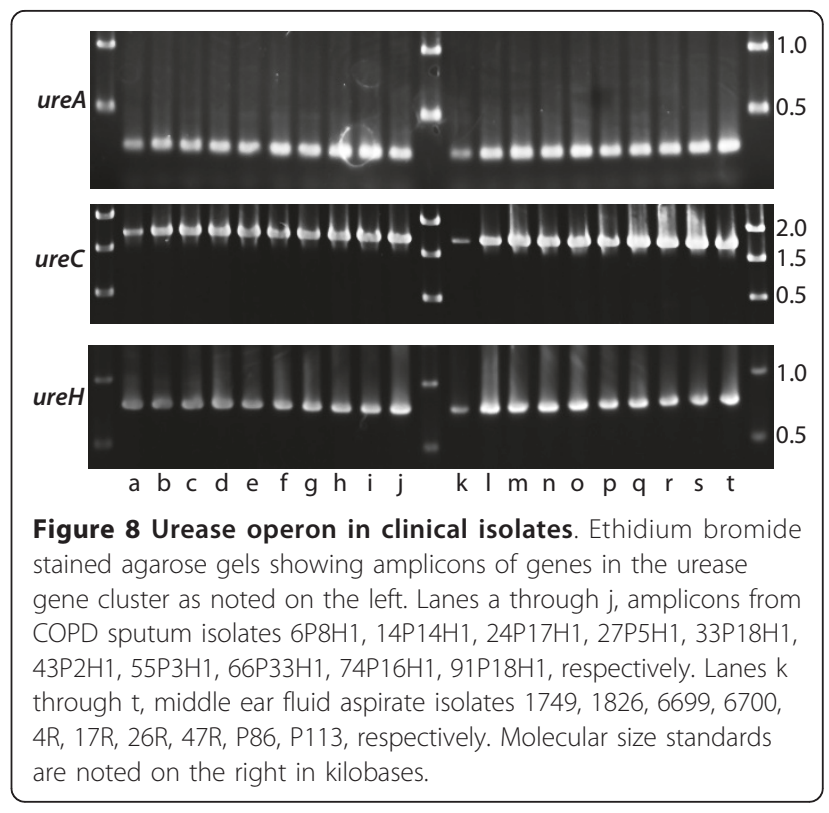

Transcription of the ureC during growth in pooled human sputum

To assess expression of urease in conditions that simulate conditions in the human respiratory tract in COPD, transcription of ure C was measured in $H$. influenzae that was grown in the presence of pooled human sputum from adults with COPD in comparison to growth in the absence of human sputum using quantitative real time PCR. Results of ureC were normalized with gyrA, a gene that is constitutively expressed [14]. Transcription of $u r e C$ in media plus sputum was $3.32 \pm 0.066$ (mean \pm standard deviation) fold greater than transcription of ure $C$ in media alone $(1.0 \pm 0.223)$. We conclude that transcription of ure $C$ is up regulated when $H$. influenzae grows in media with added human sputum compared to growth in laboratory media alone.

\section{Human antibody responses}

To determine whether urease was expressed by $H$. influenzae during infection of the human respiratory tract, 18 serum pairs from patients who experienced exacerbations due to $H$. influenzae were assayed for the development of antibody to purified recombinant urease following exacerbation.

The cutoff value for a significant percentage change between pre-exacerbation and post-exacerbation serum IgG levels was determined as previously described [41-44]. Eight control pairs of serum samples obtained 2 months apart (the same time interval for the experimental samples) from adults with COPD who were clinically stable and who had negative sputum cultures for $H$. influenzae were subjected to ELISA with the purified recombinant urease. The \% change in $\mathrm{OD}_{450}$ values between the paired 
control samples was calculated. These paired control serum samples demonstrated a $3.36 \% \pm 6.01$ (mean \pm SD) change when tested with urease. A change in OD of 9.37\% represented the upper limit of the $99 \%$ confidence interval for the control samples. Therefore, any increase in value from pre to post exacerbation serum pairs of $\leq 9.37 \%$ was regarded as a significant change. A significant increase of serum IgG antibodies to urease was seen in 7 of 18 serum pairs (Figure 9). We conclude that $H$. influenzae expresses urease during infection of the human respiratory tract and is a target of human serum antibodies in adults with COPD.

\section{Susceptibility of $H$. influenzae to acid conditions}

The ability of wild type and urease mutant to survive exposure to acid was investigated in the presence and absence of urea. Incubation of $H$. influenzae at $\mathrm{pH} 4$ in the absence of urea, resulted in $~ 35 \%$ survival of wild type and mutant strains. However, in the presence of either $50 \mathrm{mM}$ or $100 \mathrm{mM}$ urea, survival of the wild type strain increased whereas no change in survival was observed in the urease C mutant or the urease operon mutant (Figure 10). Survival of the complemented mutant closely paralleled that of wild type, supporting the conclusion that urease mediates survival in acid conditions.

\section{Discussion}

As an exclusively human pathogen, $H$. influenzae expresses molecules that mediate survival in the hostile

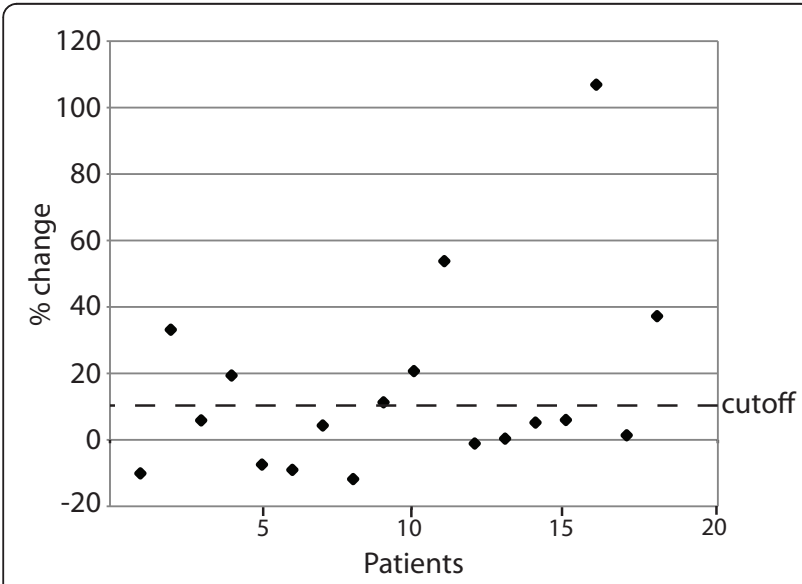

Figure 9 Human antibody response to urease. Results of ELISAs measuring serum $\lg G$ to purified recombinant urease $C$ in serum samples from adults with COPD who experienced exacerbations due to $\mathrm{H}$. influenzae. Patient numbers $(\mathrm{N}=18)$ are noted on the $\mathrm{X}$ axis. The per cent changes from pre exacerbation to post exacerbation are shown on the Y-axis. The cutoff value (dotted line) for a significant increase in antibody level was determined by averaging the difference between 8 control pairs of sera from patients who had negative sputum cultures and were clinically stable (see text). conditions of the human respiratory tract. Previous studies in animal models and in conditions that simulate those in the human airways identified urease as a molecule that is expressed in high abundance by $H$. influen$z a e$, providing evidence that urease plays a role in the pathogenesis of infection. Furthermore, urease activity may contribute to the pathogenesis of pulmonary infections due to Actinobacillus pleuropneumoniae in pigs [45]. These observations lead to the present study which is the first to characterize $H$. influenzae urease.

The $H$. influenzae urease gene cluster resembles that of other gram negative bacteria, possessing three contiguous structural genes (ureA, ureB and ureC) that encode the urease apoenzyme. Knocking out $u r e C$ alone by insertion of a nonpolar kanamycin cassette in its place resulted in complete loss of urease activity (Figure 4). Urease is a multi-subunit enzyme that requires an elaborate pathway for assembly in its active form. Associated with its three structural genes are 4 accessory genes which are necessary for synthesis of active enzyme. Based on available data from other organisms, ureEFG form a complex that keeps the apoenzyme in a conformation that will accept nickel. $H$. influenzae ureH, a structural homolog of ureD, is located downstream of the ureEFG, similar to the organization of the H. pylori urease gene cluster. H. influenzae does not have a ureR homolog, a regulatory gene that is present in some bacteria with urea-inducible urease [15]. Reverse transcriptase PCR demonstrated that the $H$. influenzae urease gene cluster is transcribed as a single transcript (Figure 7).

Urease activity in $H$. influenzae was dependent on nitrogen (ammonium chloride) availability as activity was maximal in the absence of added ammonium chloride and was markedly reduced as the concentration increased (Figure 6). This down regulation of urease expression by nitrogen sources is observed in other bacteria, including Brucella abortus and Klebsiella aerogenes and suggests that urease functions in assimilation of nitrogen from urea [23,25]. Because urea is translocated onto epithelial surfaces by secretory systems and in tissue exudates, urea is present in epithelial lining fluid of the human respiratory tract in concentrations approximately equal to that in plasma [46]. Thus, we speculate that the urease of $H$. influenzae facilitates nitrogen assimilation in the nutritionally limited environment of the human airways and the middle ear space.

Two indirect lines of evidence have suggested that $H$. influenzae expresses urease during human infection. Mason et al [14] showed that urease $\mathrm{H}$ is expressed during infection of the middle ear in chinchillas and $\mathrm{Qu}$ et al [13] showed that urease $C$ was expressed in markedly increased abundance during growth in pooled human sputum. The present study advances those observations by showing directly that $H$. influenzae expresses urease 


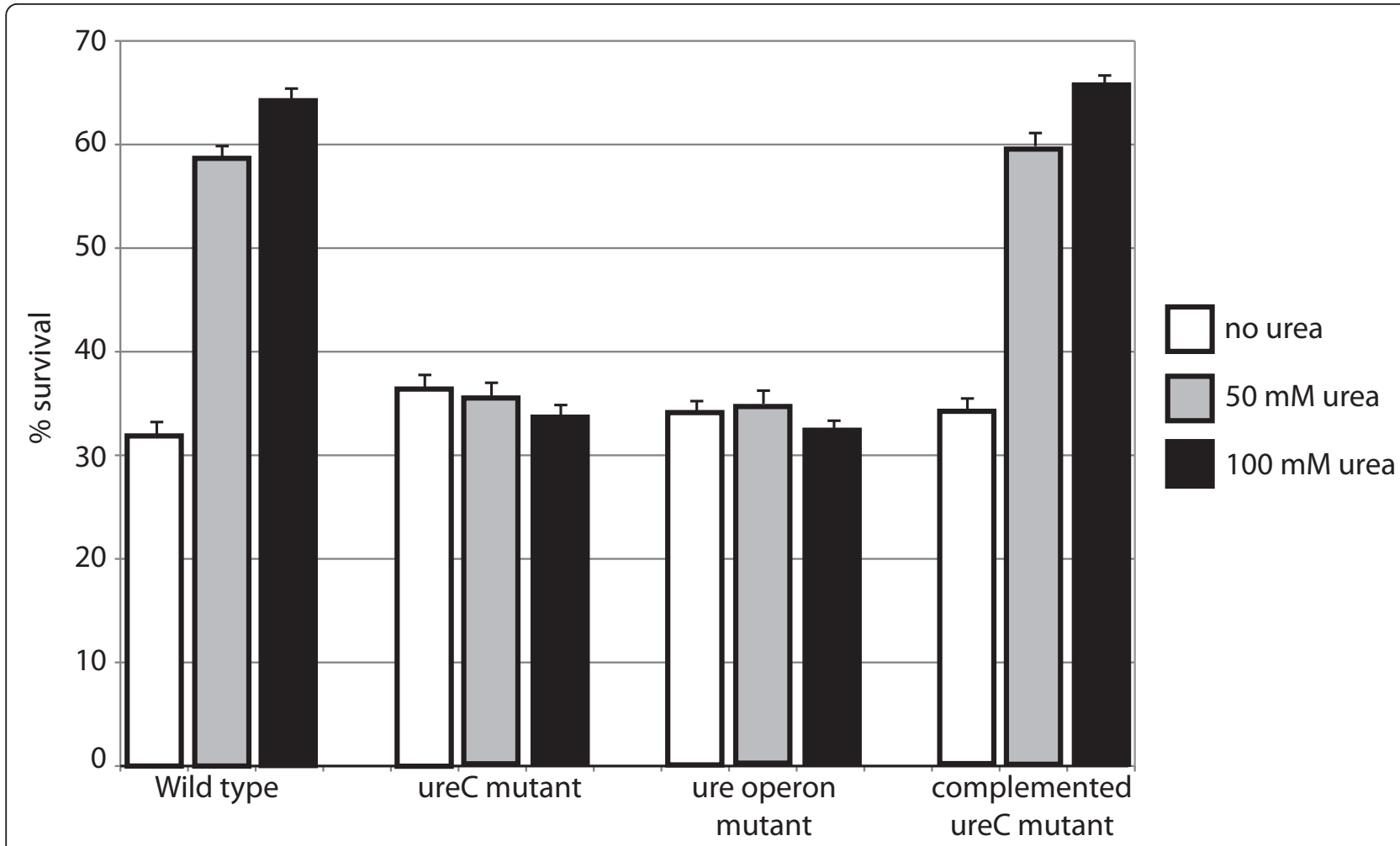

Figure 10 Urease mediates survival at acid pH. Survival of $\mathrm{H}$. influenzae strain $11 \mathrm{P} 6 \mathrm{H}$ and urease mutants at pH 4. Bacteria were suspended in buffer at pH 4 and incubated for 30 minutes at $37^{\circ} \mathrm{C}$. Urea concentrations are as follows: white bars: no urea; gray bars: $50 \mathrm{mM}$ urea; black bars: $100 \mathrm{mM}$. Bars indicate \%survival calculated from colony counts performed at time 0 and 30 minutes. Values represent the mean of 3 independent experiments and error bars indicate standard deviation.

during airway infection in adults who experienced exacerbations of COPD. Paired pre and post infection serum samples were subjected to ELISA with purified recombinant urease $C$ to characterize the antibody response to urease following infection. Because the pre infection serum samples were collected one month prior to acquisition of the infecting strain of $H$. influenzae, an increase in the level of antibody to urease indicates the development of new antibodies following infection. All serum samples had detectable levels of antibody to urease and 7 of 18 patients developed significantly increased levels following infection compared to their own pre infection levels (Figure 9). This frequency of antibody response following bacterial infection is typical as heterogeneity in immune responses to bacterial antigens among individuals is a hallmark of COPD [47,48]. Note also that recombinant purified urease $C$ was used in the ELISA and this protein is only one of 3 proteins that comprise the urease complex; thus, a urease Cbased ELISA may underestimate the frequency of new antibody responses to urease following infection. These results indicate that $H$. influenzae expresses urease during exacerbations of COPD and that urease is a target of human antibody responses.
An important result from the present study is the observation that urease functions to mediate survival of $H$. influenzae in an acid environment. Urease mediates survival in low $\mathrm{pH}$ as a virulence mechanism in other bacteria, notably $H$. pylori which must survive in the stomach. Other selected respiratory pathogens express urease but the role of urease in pathogenesis of respiratory tract infection is unclear $[49,50]$. Microenvironments in the human respiratory tract are likely low $\mathrm{pH}$, consistent with the speculation that the high level of expression of urease in the respiratory tract mediates survival in acid microenvironments. Furthermore, $H$. influenzae is now known to invade and persist in respiratory epithelial cells and macrophages, suggesting that withstanding lower $\mathrm{pH}$ in intracellular compartments may be a virulence mechanism [51-53].

\section{Conclusions}

The present study demonstrates that 1) The ureA-ureH gene cluster of $H$. influenzae is exclusively responsible for urease production because knock out mutants show no urease activity. 2) Genes of the urease gene cluster are transcribed as a single transcript. 3) Urease expression is regulated in response to nitrogen availability. 4) The optimal 
$\mathrm{pH}$ for urease activity is 7.0.5) The urease operon is present in all strains of $H$. influenzae tested including otitis media and COPD isolates. 6) Transcription of the ure operon is up regulated when $H$. influenzae grows in human sputum, consistent with the earlier observation established by proteomics analysis [13]. 7) Urease is expressed in the human airways during infection in adults with COPD and is the target of human antibody responses. And 8) Urease mediates survival of $H$. influenzae in an acid environment. In view of the high level of expression of urease in the respiratory tract, future work will focus on elucidating the role of urease as a virulence factor for $H$. influenzae infection of the human respiratory tract.

\section{Methods}

\section{Bacterial strains and growth conditions}

$H$. influenzae $11 \mathrm{P} 6 \mathrm{H}$ was isolated from the sputum of an adult with COPD who was experiencing an exacerbation as part of a prospective study at the Buffalo VA Medical Center [54]. The following strains were also isolated from the sputum of adults with COPD as part of the same study: 14P14H1, 24P17H1, 27P5H1, 33P18H1, 43P2H1, 55P3H1, 66P33H1, 74P16H1, 91P18H1. Each strain was isolated from a different subject.

$H$. influenzae strains $1749,1826,6699,6700,4 \mathrm{R}, 17 \mathrm{R}$, 26R, 47R, P86 and P113 were isolated from middle ear fluid obtained by tympanocentesis from children with otitis media in either Buffalo NY or Rochester NY. All strains were identified as $H$. influenzae by growth requirement for hemin and nicotinamide adenine dinucleotide (NAD), absence of porphyrin production and absence of hemolysis. Each isolate was also subjected to immunoblot assay with monoclonal antibody 7F3 that recognizes outer membrane P6 to exclude the possibility of non hemolytic $H$. haemolyticus [55].

H. influenzae was grown on chocolate agar at $37^{\circ} \mathrm{C}$ in $5 \% \mathrm{CO}_{2}$ or in brain heart infusion broth supplemented with hemin and NAD each at $10 \mu \mathrm{g} / \mathrm{ml}$ with shaking at $37^{\circ} \mathrm{C}$. In selected experiments, $H$. influenzae was grown in chemically defined media (Table 1).

Chemically competent E. coli strains Top10 and BL21 (DE3) were obtained from Invitrogen (Carlsbad, CA) and were grown at $37^{\circ} \mathrm{C}$ on Luria-Bertani (LB) plates or in LB broth supplemented with antibiotics as noted in individual experiments. Plasmid PSPEC1 was kindly provided by Lauren Bakaletz and Robert Munson [39].

\section{Construction of mutants}

A mutant lacking $u r e C$, the gene that encodes the alpha subunit of urease, was constructed using overlap
Table 1 Composition of chemically defined media (CDM)

\begin{tabular}{|c|c|}
\hline Reagent & Concentration \\
\hline $\mathrm{NaCl}$ & $0.1 \mathrm{M}$ \\
\hline $\mathrm{K}_{2} \mathrm{SO}_{4}$ & $5.75 \mathrm{mM}$ \\
\hline $\mathrm{Na}_{2} \mathrm{EDTA}$ & $4 \mathrm{mM}$ \\
\hline $\mathrm{NH}_{4} \mathrm{Cl}$ & $4 \mathrm{mM}$ \\
\hline $\mathrm{K}_{2} \mathrm{HPO}_{4}$ & $2 \mathrm{mM}$ \\
\hline $\mathrm{KH}_{2} \mathrm{PO}_{4}$ & $2 \mathrm{mM}$ \\
\hline Thiamine $\mathrm{HCl}$ & $6 \mu \mathrm{M}$ \\
\hline Thiamine pyrophosphate & $1 \mu \mathrm{M}$ \\
\hline Pantothenic acid & $8 \mu \mathrm{M}$ \\
\hline d-Biotin & $12 \mu \mathrm{M}$ \\
\hline Glucose & $0.5 \%$ \\
\hline Hypoxanthine & $0.375 \mathrm{mM}$ \\
\hline Uracil & $0.45 \mathrm{mM}$ \\
\hline L-aspartic acid & $3.75 \mathrm{mM}$ \\
\hline L-glutamic acid $\mathrm{HCl}$ & $7.5 \mathrm{mM}$ \\
\hline L-arginine & $0.875 \mathrm{mM}$ \\
\hline Glycine $\mathrm{HCl}$ & $0.225 \mathrm{mM}$ \\
\hline L-serine & $0.475 \mathrm{mM}$ \\
\hline L-leucine & $0.7 \mathrm{mM}$ \\
\hline L-isoleucine & $0.225 \mathrm{mM}$ \\
\hline L-valine & $0.525 \mathrm{mM}$ \\
\hline L-tyrosine & $0.4 \mathrm{mM}$ \\
\hline L-cysteine $\mathrm{HCl}$ & $0.35 \mathrm{mM}$ \\
\hline L-cystine & $0.15 \mathrm{mM}$ \\
\hline L-proline & $0.45 \mathrm{mM}$ \\
\hline L-tryptophan & $0.4 \mathrm{mM}$ \\
\hline L-threonine & $0.425 \mathrm{mM}$ \\
\hline L-phenylalanine & $0.15 \mathrm{mM}$ \\
\hline L-asparagine & $0.2 \mathrm{mM}$ \\
\hline L-glutamine & $0.35 \mathrm{mM}$ \\
\hline L-histidine $\mathrm{HCl}$ & $0.125 \mathrm{mM}$ \\
\hline L-methionine & $0.1 \mathrm{mM}$ \\
\hline L-alanine & $1.125 \mathrm{mM}$ \\
\hline L-lysine & $0.35 \mathrm{mM}$ \\
\hline Glutathione reduced & $0.15 \mathrm{mM}$ \\
\hline HEPES & $42 \mathrm{mM}$ \\
\hline $\mathrm{NaHCO}_{3}$ & $0.125 \mathrm{mM}$ \\
\hline $\mathrm{Na}$ acetate trihydrate & $6.25 \mathrm{mM}$ \\
\hline Choline chloride salt & $0.05 \mathrm{mM}$ \\
\hline Myo-inositol & $1 \mu \mathrm{M}$ \\
\hline $\mathrm{MgCl}_{2}$ & $2.5 \mathrm{mM}$ \\
\hline $\mathrm{CaCl}_{2}$ & $0.6 \mathrm{mM}$ \\
\hline $\mathrm{Fe}\left(\mathrm{NO}_{3}\right)_{3}$ & $0.1 \mathrm{mM}$ \\
\hline Nicotinamide adenine dinucleotide & $0.02 \mathrm{mM}$ \\
\hline Protoporphyrin IX & $0.02 \mathrm{mM}$ \\
\hline Histidine & $6 \mu \mathrm{M}$ \\
\hline Triethanolamine & $0.01 \%$ \\
\hline
\end{tabular}


extension PCR. The transforming DNA to accomplish this was composed of 3 fragments: 1) a $\sim 1 \mathrm{~kb}$ fragment of DNA corresponding to sequence upstream of ureC, 2) the nonpolar kanamycin resistance cassette AphA-3 [56], 3) a $\sim 1 \mathrm{~kb}$ fragment of DNA corresponding to sequence downstream of ureC. Primers for each of the fragments were designed with $10 \mathrm{bp}$ overlaps with complementary overlapping regions with the adjacent fragment (Table 2). The 3 fragments were amplified using the high fidelity DNA polymerase Pfu (Stratagene, Cedar Creek, TX) and were purified using the Qiaquick PCR purification kit (Qiagen, Valencia, CA). Amplicons were mixed in the absence of additional primers in a PCR with $P f u$ and were subjected to a PCR program consisting of 10 cycles with a denaturing step at $94^{\circ} \mathrm{C}$ for 30 sec, an annealing step at $50^{\circ} \mathrm{C}$ for $1 \mathrm{~min}$ and an elongation step at $72^{\circ} \mathrm{C}$ for $5 \mathrm{~min}$. The fusion product was subsequently amplified by Pfu with primers 539frag $15^{\prime}$ and 539frag3 3' (Table 2). This amplicon consisted of 1020 bp sequence upstream of ureC and $1029 \mathrm{bp}$ sequence downstream of $u r e C$ flanking the kanamycin cassette.

The fragment was transformed into $H$. influenzae strain $11 \mathrm{P} 6 \mathrm{H}$ which was made competent by the method of Herriott et al [57] using the transformation protocol of Poje and Redfield [58] as previously described [59]. Transformants were selected on chocolate agar containing $15 \mu \mathrm{g} / \mathrm{ml}$ of robostimycin. A mutant was obtained $\left(11 \mathrm{P} 6 \mathrm{H}\right.$ ure $\left.\mathrm{C}^{-}\right)$and allelic exchange was verified by PCR analysis and sequencing as detailed in Results.

A mutant in which the entire urease gene cluster was knocked out and replaced with a kanamycin cassette was constructed (11P6Hure $)^{-}$with the same strategy using the primers noted in Table 2. The mutant was verified by PCR analysis, Southern blot assay and sequencing.

\section{Complementation of ureC mutant}

Complementation was accomplished by using the plasmid pSPEC1 [39]. A fragment containing the ure C gene and $740 \mathrm{bp}$ upstream to include the promoter of the urease operon and $300 \mathrm{bp}$ downstream was amplified from genomic DNA of strain $11 \mathrm{P} 6 \mathrm{H}$ and ligated into pSPEC1 at BamHI and EcoRI restriction sites (Table 2). After confirming the insert sequence of the resulting plasmid (p UreCspec), H. influenzae 11P6H was electroporated with $\mathrm{p}$ UreCspec that had been methylated with CpG methylase (New England Biolabs) in a 0.1-cm cuvette $(200 \Omega, 2.5 \mathrm{kV}, 25 \mu \mathrm{F})$. Cells were plated on chocolate agar containing $200 \mu \mathrm{g} / \mathrm{ml}$ of spectinomycin, incubated overnight and the complemented mutant $11 \mathrm{P} 6 \mathrm{H}$ ureC $^{-}$(p UreCspec) was obtained. This complemented mutant was grown in the presence of spectinomycin for all experiments.

\section{Southern blot assay}

Southern blot assays were performed with genomic DNA restricted with EcoRI with the Hoefer TransVac vacuum blotting unit following the manufacturer's instructions (Hoefer, SanFrancisco, CA). Probes were biotinylated with the NEBlot Phototope kit (New England BioLabs) and blots were developed with the Phototope-Star Detection Kit (New England BioLabs) using the manufacturer's instructions.

\section{Measurement of urease activity}

Urease activity was determined by measuring the amount of ammonia released from urea $[25,60]$. To prepare whole bacterial cell extracts, overnight cultures (5 $\mathrm{ml}$ ) were centrifuged at $2500 \times \mathrm{g}$ for $10 \mathrm{~min}$ at $4^{\circ} \mathrm{C}$ and the pellet was suspended in $5 \mathrm{ml}$ of phosphate buffered saline (PBS) pH 7.5. Cells were disrupted by sonication with three 10 second bursts (Branson Sonifier 450, output control 5). One $\mathrm{ml}$ of the resulting suspension was centrifuged at $16,000 \times \mathrm{g}$ for $2 \mathrm{~min}$ to remove unbroken cells and $10 \mu \mathrm{l}$ of the sonic extract were added to $200 \mu \mathrm{l}$ of PBS containing $50 \mathrm{mM}$ urea and incubated at $37^{\circ} \mathrm{C}$ for $30 \mathrm{~min}$. To perform the urease assay, $125 \mu \mathrm{l}$ of sonic extract were mixed with $250 \mu \mathrm{l}$ alkaline hypochlorite, $250 \mu \mathrm{l}$ phenol nitroprusside and $1 \mathrm{ml}$ of water and the assay was incubated for $30 \mathrm{~min}$ at $37^{\circ} \mathrm{C}$. A volume of $200 \mu \mathrm{l}$ was removed and placed into wells of a 96 well plate and the $\mathrm{OD}_{595}$ was measured in an ELISA plate reader. Urease activity was determined by the use of a standard curve using $\mathrm{NH}_{4} \mathrm{Cl}(0.156 \mathrm{mM}$ to $2.5 \mathrm{mM})$ performed simultaneously with each assay. Urease activity was expressed in $\mu$ moles of urea hydrolyzed per minute.

\section{Expression and purification of recombinant protein encoded by ureC}

The $u r e C$ gene was amplified by PCR from genomic DNA of $H$. influenzae strain 11P6H using oligonucleotide primers noted in Table 2 and cloned into pET101 D-TOPO (Invitrogen, Carlsbad, CA), which places a 6 histidine tag on the carboxy terminus of the recombinant protein, using manufacturer's instructions. Chemically competent $E$. coli TOP 10 cells were transformed with the recombinant plasmid and transformants were selected by plating on LB plates containing $50 \mu \mathrm{g} / \mathrm{ml}$ of carbenicillin. The plasmid (p539) from a transformant was confirmed to have the ureC gene by PCR and by sequence determination. Plasmid p539 was purified using the Qiagen plasmid mini purification system and transformed into chemically competent E. coli BL21 (DE3) for expression. To express recombinant protein, $2.5 \mathrm{ml}$ of overnight culture was used to inoculate $50 \mathrm{ml}$ of LB broth containing $300 \mu \mathrm{g} / \mathrm{ml}$ of carbenicillin. When the culture reached an $\mathrm{OD}_{600}$ of $\sim 0.6$, expression 
Table 2 Oligonucleotide primer sequences

\begin{tabular}{|c|c|c|c|}
\hline Primer & Gene & Direction & Sequence $^{1}$ \\
\hline \multicolumn{4}{|c|}{ Construction of ureC mutant } \\
\hline 539 frag1 $5^{\prime}$ & ureC upstream & Forward & 5'-GACCTTTACCCACAGCTAAT-3' \\
\hline 539 frag1 $3^{\prime}$ & ureC upstream & Reverse & $\begin{array}{l}\text { 5'-TAGTTAGTCACTTGAAATTGTTA } \\
\text { ATGCCAT-3' }\end{array}$ \\
\hline 539 frag2 $5^{\prime}$ & Kanamycin cassette & Forward & $\begin{array}{l}\text { 5'-CAATTTCAAGTGACTAACTAGGA } \\
\text { GGAATAA-3' }\end{array}$ \\
\hline 539 frag2 $3^{\prime}$ & Kanamycin cassette & Reverse & $\begin{array}{l}\text { 5'-TGACCCAATGCATTATTCCCTCC } \\
\text { AGGTACT-3' }\end{array}$ \\
\hline 539 frag3 $5^{\prime}$ & ureC downstream & Forward & $\begin{array}{l}\text { 5'-GGGAATAATGCATTGGGTCAGC } \\
\text { GATA-3' }\end{array}$ \\
\hline 539 frag3 3' & ureC downstream & Reverse & 5'-ATCGCACACCGAGTTTG-3' \\
\hline \multicolumn{4}{|c|}{ Cloning of ureC into pSPEC1 to complement ureC mutation } \\
\hline $\begin{array}{l}\text { 539promoter } \\
\text { F1 }\end{array}$ & ureA upstream & Forward & $\begin{array}{l}\text { 5'-GAGAGGATCCGTAAAATTCGCTG } \\
\text { ACTITCG-3' }\end{array}$ \\
\hline 539 C R1 & ureC downstream & Reverse & $\begin{array}{l}\text { 5'ATATGAATTCGCTACTTCACGCC } \\
\text { CCGTA-3' }\end{array}$ \\
\hline \multicolumn{4}{|c|}{ Construction of urease operon mutant } \\
\hline 539 Op frag1 F1 & ureA upstream & Forward & 5'-TACACCTTCCTTGCCCAC-3' \\
\hline 539 Op frag1 R1 & ureA upstream & Reverse & 5'-TAGTTAGTCAATTTTCATTCCTTAAT-3' \\
\hline 539 Op frag2 F1 & Kanamycin cassette & Forward & $\begin{array}{l}\text { 5'-GAATGAAAATTGACTAACTAG } \\
\text { GAGGAATAA-3' }\end{array}$ \\
\hline 539 Op frag2 R1 & Kanamycin cassette & Reverse & $\begin{array}{l}\text { 5'-ACCAATTTTCCATTATTCCCTCCA } \\
\text { GGTACT-3' }\end{array}$ \\
\hline 5390p frag3 F1 & ureA downstream & Forward & $\begin{array}{l}\text { 5'-GGGAATAATGGAAAATTGGTAG } \\
\text { GCTAT-3' }\end{array}$ \\
\hline 5390p frag3 R1 & ureA downstream & Reverse & 5'-CAGATGTTGCTTCAATTAAG-3' \\
\hline \multicolumn{4}{|c|}{ Subjecting multiple strains to PCR to assess presence of urease operon } \\
\hline UreaseA F1 & ureA & Forward & 5'-ATGCACTTAACTTCCAGAG-3' \\
\hline UreaseA R1 & ureA & Reverse & 5'-TTATCTGATTGGATTATGC-3' \\
\hline $539 \mathrm{F1}$ & ureC & Forward & 5'-CAACATGGCATTAACAATTTCAAG-3' \\
\hline 539 R1 & ureC & Reverse & 5'-TTAGAATAGGAAATATCGCTG-3' \\
\hline UreaseH F1 & ureH & Forward & 5'-ATGAACAGTAAATTATCC-3' \\
\hline UreaseHR1 & ureH & Reverse & 5'-GAATTTGCTCTGCACGACA-3' \\
\hline \multicolumn{4}{|c|}{ Cloning of ureC gene to express recombinant protein } \\
\hline $539 \mathrm{F1}$ & ureC & Forward & 5'-CAACATGGCATTAACAATTTCAAG-3' \\
\hline 539 R1 & ureC & Reverse & 5'-TTAGAATAGGAAATATCGCTG-3' \\
\hline \multicolumn{4}{|c|}{ Performing RT PCR } \\
\hline UreA-UreB F1 & ureA, ureB & Forward & 5'-ATGAGTGTAGCGGAAGTG-3' \\
\hline UreA-UreB R1 & ureA, ureB & Reverse & 5'-ACGTTAAACGCATTCCGC-3' \\
\hline UreB-UreC F1 & ureB, ureC & Forward & 5'-TGAAACCAATAATGCCCT-3' \\
\hline UreB-UreC R1 & ureB, ureC & Reverse & 5'-TTGCGTGCGTACCATCAGC-3' \\
\hline UreC-UreE F1 & ureC, ureE & Forward & 5'-GGTATTGCGGAGCATATTGG-3' \\
\hline UreC-UreE R1 & ureC, ureE & Reverse & 5'-GAATGACTGTGAGAATGCC-3' \\
\hline UreE-UreF F1 & ureE, ureF & Forward & 5'-GCTTGAAACACGATGATG-3' \\
\hline UreE-UreF R1 & ureE, ureF & Reverse & 5'-TGATTGCACCGACTGCTG-3' \\
\hline UreF-UreG F1 & ureF, ureG & Forward & 5'-TGCCTTCGATGCAATGAAC-3' \\
\hline UreF-UreG R1 & ureF, ureG & Reverse & 5'-AGCACCAACGAATGGAGC-3' \\
\hline UreG-UreH F1 & ureG, ureH & Forward & 5'-AGTTTGCTTCCACCAGAGC-3' \\
\hline UreG-UreH R1 & ureG, ureH & Reverse & 5'-GTTCGTCATTCAACACCC-3' \\
\hline
\end{tabular}

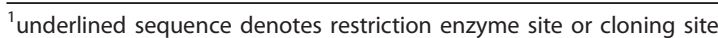


was induced by the addition of IPTG to a concentration of $4 \mathrm{mM}$. Cells were harvested by centrifugation after 4 hours and recombinant protein was purified with Talon Metal Affinity resin (Clontech, Mountain View, CA) using manufacturer's instructions.

The purified recombinant protein was refolded by dialysis in buffer with sequentially decreasing concentrations of L-arginine. The buffer contained $0.15 \mathrm{M} \mathrm{NaCl}$, $20 \mathrm{mM}$ tris $\mathrm{pH}$ 9, with decreasing concentrations (1 M, $0.5 \mathrm{M}, 5 \mathrm{mM}$ ) of L-arginine. Protease Arrest ${ }^{\mathrm{TM}}$ (EMD Chemicals, Gibbstown NJ) was added to purified protein.

\section{Development of antiserum to urease $C$}

Purified recombinant urease $\mathrm{C}$ was sent to Covance (Denver, PA) for antibody production in New Zealand white rabbits using a 59 day protocol. All applicable regulations for animal treatment were followed in accordance with the recommendations in the Guide for the Care and Use of Laboratory Animals of the National Institutes of Health (http://oacu.od.nih.gov/regs/guide/ guide.pdf). Specific pathogen free rabbits received 250 $\mu \mathrm{g}$ of purified protein with complete Freund's adjuvant subcutaneously on day 0 , followed by $125 \mu \mathrm{g}$ of protein with incomplete Freund's adjuvant subcutaneously on days 21 and 49. Blood was obtained on day 59.

The rabbit antiserum was adsorbed with $11 \mathrm{P} 6 \mathrm{H}$ ure $\mathrm{C}^{-}$ (urease $\mathrm{C}$ mutant) to remove background rabbit antibodies to $H$. influenzae. To accomplish this, bacteria were grown to log phase in broth, centrifuged to pellet bacteria, washed in PBS and suspended in $1 \mathrm{ml}$ of a 1:1000 dilution of rabbit antiserum. After incubation for 30 $\min$ at $4^{\circ} \mathrm{C}$, bacteria were removed by centrifugation. This process was repeated 3 more times. After the last adsorption, the serum was filter sterilized.

\section{Reverse transcriptase-PCR}

Bacteria were grown in chemically defined media (Table 1) and RNA was isolated using a QIAGEN RNeasy kit and a Qiashredder column (QIAGEN, Valencia, CA) following the manufacturer's instructions, with an additional incubation with RNase-free DNaseI (Promega) for $30 \mathrm{~min}$ at $37^{\circ} \mathrm{C}$. Reverse transcriptase PCR (RT-PCR) was performed using a QIAGEN OneStep RT-PCR kit and RNaseOut inhibitor (Invitrogen, Carlsbad, CA). Primers were designed to amplify fragments that would be predicted to correspond to transcripts that span adjacent genes in the urease gene cluster (Table 2). To exclude the possibility of contaminating DNA, parallel reactions with Taq DNA polymerase (HotMaster Mix; Eppendorf, Hamburg, Germany) were performed. Following amplification, samples were electrophoresed in $1 \%$ agarose gels and stained with ethidium bromide.

\section{COPD Study Clinic}

The COPD study clinic at the Buffalo Veterans Affairs Medical Center is an ongoing prospective study that was started in 1994 [54]. The study was approved by the Health Sciences Institutional Review Board of the University at Buffalo and the Human Studies Subcommittee of the Western New York Veterans Affairs Healthcare System. All study participants provided written informed consent. To be included in this study, patients must have chronic bronchitis as defined by the American Thoracic Society [61] and must be willing to attend the study clinic monthly. Patients with asthma, malignancies, or other immunocompromising illnesses were excluded. Patients were seen monthly and at times when an exacerbation was suspected. At each visit clinical criteria were used to determine whether patients were experiencing an exacerbation or whether they were clinically stable as previously described [54]. Additionally at each visit, serum and expectorated sputum samples were collected. Bacteria present in the sputum were identified using standard techniques. Serum and bacteria obtained from sputum cultures were stored at $-80^{\circ} \mathrm{C}$.

An exacerbation of COPD caused by $H$. influenzae was defined by the onset of clinical symptoms of an exacerbation simultaneous with the acquisition of a new strain of $H$. influenzae that had not previously been isolated from that patient based on molecular typing [54]. Serum samples collected one month prior to acquisition of the strain and one month following the exacerbation were used to analyze human serum antibody responses to the purified recombinant urease $\mathrm{C}$.

\section{Pooled human sputum}

Expectorated sputum samples were collected from subjects in the COPD Study Clinic and were processed for culture as previously described $[54,62]$. Briefly, sputum samples were homogenized by incubation at $37^{\circ} \mathrm{C}$ for 15 minutes with an equal volume of $0.1 \%$ dithiothreitol. After an aliquot was removed for quantitative culture, sputum samples were centrifuged at $27,000 \times$ g for 30 minutes at $4^{\circ} \mathrm{C}$ and supernatants were stored at $-80^{\circ} \mathrm{C}$ until used. Samples from patients who were receiving antibiotics and samples that grew potential pulmonary bacterial pathogens in culture were excluded. Supernatants from approximately 100 sputum samples from 30 individuals were pooled for the purpose of growing bacteria in pooled sputum supernatants [13]. To render the sputum supernatants sterile, the pooled samples were placed in Petri dishes and exposed to UV light in a cell culture hood for approximately 10 minutes. An aliquot was plated on chocolate agar and no growth was detected after overnight incubation. 


\section{Quantitative real time PCR}

$H$. influenzae was grown in the presence pooled human sputum from adults with COPD to simulate conditions in the human respiratory tract. To assess transcription of ureC, strain $11 \mathrm{P} 6 \mathrm{H}$ was grown overnight in chemically defined media $(\mathrm{CDM})$ at $37^{\circ} \mathrm{C}$ with shaking to which pooled human sputum supernatant of $20 \%$ of the volume of the culture was added [13]. A second culture was grown simultaneously in CDM to which PBS containing $0.1 \%$ dithiothreitol was added to $20 \%$ of the total volume as a control for the sputum supernatant. Cells were harvested by centrifugation at $10,000 \times \mathrm{g}$ for 10 minutes at $4^{\circ} \mathrm{C}$. Cells were washed by suspending in cold PBS and centrifuging again using the same conditions. Bacterial RNA was isolated as described above (Reverse Transcriptase-PCR).

Quantitative real time PCR was performed using the BioRad MyiQ Real-Time PCR Detection System. Oligonucleotide primers pairs (Table 2) were designed with Primer 3 software. Each reaction mixture contained 5 ng purified RNA, $100 \mathrm{nM}$ of each primer, $12.5 \mu \mathrm{l} 2 \times$ Sybr Green Supermix (BioRad), $0.125 \mu$ l reverse transcriptase and $6.375 \mu \mathrm{l}$ water. Controls lacking reverse transcriptase or RNA template contained the appropriate volume of water in place of enzyme or template. Each purified RNA sample was tested for DNA contamination prior to proceeding with the real time PCR assay. Results with $g y r A$, a constitutively expressed gene, were measured in both growth conditions and used to normalize the results with $u r e C$ in the corresponding growth condition. These normalized results were used to calculate the fold change expression of ure $C$ during growth in CDM plus sputum compared to CDM alone. BioRad iQ5 software was used to analyze data.

\section{Enzyme-linked immunosorbent assay (ELISA)}

Eighteen pre and post exacerbation serum pairs from adults with COPD followed in the COPD Study Clinic were subjected to ELISA to detect the development of new IgG antibodies in serum to urease C [48]. The change in antibody level from pre-exacerbation to postexacerbation samples was calculated using the following formula: $\%$ change $=[($ post OD - pre OD $) /$ pre OD $] \times$ 100. Paired pre-exacerbation and post-exacerbation samples were always tested in the same assay. The cutoff value for a significant percentage change between preexacerbation and post-exacerbation serum IgG levels was determined by studying 8 control pairs of serum samples obtained 2 months apart (the same time interval for the experimental samples) from patients who were clinically stable and who had negative sputum cultures for $H$. influenzae as described previously $[42,43,48,63]$.

\section{Susceptibility of $H$. influenzae to acid}

$H$. influenzae wild type and mutant strains were grown in broth to log phase, harvested by centrifugation and suspended to a concentration of $\sim 10^{7}$ colony forming units $/ \mathrm{ml}$ in PBS adjusted to varying $\mathrm{pH}$. Cells were incubated in the presence or absence of urea $(50 \mathrm{mM}$ or 100 $\mathrm{mM}$ ) and dilutions of bacteria were plated at time 0 and at $30 \mathrm{~min}$. Bacteria were counted after overnight incubation on chocolate agar.

\section{Acknowledgements and Funding}

This work was supported by National Institutes of Health grant Al 19641 to TFM.

\section{Author details}

'Division of Infectious Diseases, Department of Medicine, 701 Ellicott Street, University at Buffalo, State University of New York, Buffalo, NY 14203, USA. ${ }^{2}$ Department of Microbiology, 701 Ellicott Street, University at Buffalo, State University of New York, Buffalo, NY 14203, USA. ${ }^{3}$ New York State Center of Excellence in Bioinformatics and Life Sciences; 701 Ellicott Street, University at Buffalo, State University of New York, Buffalo, NY 14203, USA.

\section{Authors' contributions}

TFM was responsible for the conception and design of the study, analysis and interpretation of data, and drafting the manuscript. ALB made

substantial contribution to the design of the study, acquired the data by performing the experiments and contributed important intellectual content to revisions of the manuscript. Both authors read and approved the final manuscript.

Received: 24 April 2011 Accepted: 16 August 2011

Published: 16 August 2011

\section{References}

1. Murphy TF, Faden H, Bakaletz LO, Kyd JM, Forsgren A, Campos J, Virji M Pelton SI: Nontypeable Haemophilus influenzae as a pathogen in children. Pediatr Infect Dis J 2009, 28(1):43-48.

2. Sethi S, Murphy TF: Infection in the pathogenesis and course of chronic obstructive pulmonary disease. N Engl J Med 2008, 359(22):2355-2365.

3. Murphy TF: Respiratory infections caused by non-typeable Haemophilus influenzae. Curr Opin Infect Dis 2003, 16(2):129-134.

4. Zalacain R, Sobradillo V, Amilibia J, Barron J, Achotegui V, Pijoan J, Llorente $\mathrm{L}$ : Predisposing factors to bacterial colonization in chronic obstructive pulmonary disease. Eur Respir J 1999, 13:343-348.

5. Soler N, Torres A, Ewig S, Gonzalez J, Celis R, El-Ebiary M, Hernandez C, Rodriguez-Roisin R: Bronchial microbial patterns in severe exacerbations of chronic obstructive pulmonary disease (COPD) requiring mechanical ventilation. Am J Respir Crit Care Med 1998, 157:1498-1505.

6. Sethi S, Maloney J, Grove L, Wrona C, Berenson CS: Airway inflammation and bronchial bacterial colonization in chronic obstructive pulmonary disease. Am J Respir Crit Care Med 2006, 173(9):991-998.

7. Monso E, Ruiz J, Rosell A, Manterola J, Fiz J, Morera J, Ausina V: Bacterial infection in chronic obstructive pulmonary disease. A study of stable and exacerbated outpatients using the protected specimen brush. Am J Respir Crit Care Med 1995, 152:1316-1320.

8. Drost EM, Skwarski KM, Sauleda J, Soler N, Roca J, Agusti A, MacNee W: Oxidative stress and airway inflammation in severe exacerbations of COPD. Thorax 2005, 60(4):293-300.

9. Gerritsen WB, Asin J, Zanen P, van den Bosch JM, Haas FJ: Markers of inflammation and oxidative stress in exacerbated chronic obstructive pulmonary disease patients. Respir Med 2005, 99(1):84-90.

10. Dekhuijzen PN, Aben KK, Dekker I, Aarts LP, Wielders PL, van Herwaarden $C L$, Bast $A$ : Increased exhalation of hydrogen peroxide in patients with stable and unstable chronic obstructive pulmonary disease. Am J Respir Crit Care Med 1996, 154(3 Pt 1):813-816.

11. Barnes PJ: The cytokine network in chronic obstructive pulmonary disease. Am J Respir Cell Mol Biol 2009, 41(6):631-638. 
12. Barnes PJ: Chronic obstructive pulmonary disease. N Engl J Med 2000, 343(4):269-280.

13. Qu J, Lesse AJ, Brauer AL, Cao J, Gill SR, Murphy TF: Proteomic expression profiling of Haemophilus influenzae grown in pooled human sputum from adults with chronic obstructive pulmonary disease reveal antioxidant and stress responses. BMC Microbiol 2010, 10:162.

14. Mason KM, Munson RS Jr, Bakaletz LO: Nontypeable Haemophilus influenzae gene expression induced in vivo in a chinchilla model of otitis media. Infect Immun 2003, 71(6):3454-3462.

15. Mobley HL, Island MD, Hausinger RP: Molecular biology of microbial ureases. Microbiol Rev 1995, 59(3):451-480.

16. Mobley HLT: Urease. In Helicobacter pylori: Physiology and Genetics. Edited by: Mobley HLT, Mendz GL, Hazell SL. Washington DC: ASM Press; 2001:, 2011/02/04 edn

17. Molnar B, Galamb O, Sipos F, Leiszter K, Tulassay Z: Molecular pathogenesis of Helicobacter pylori infection: the role of bacterial virulence factors. Dig Dis 2010, 28(4-5):604-608.

18. Schoep TD, Fulurija A, Good F, Lu W, Himbeck RP, Schwan C, Choi SS, Berg DE, Mittl PR, Benghezal M, Marshall BJ: Surface properties of Helicobacter pylori urease complex are essential for persistence. PLoS One 2010, 5(11):e15042..

19. Stingl K, Altendorf K, Bakker EP: Acid survival of Helicobacter pylori: how does urease activity trigger cytoplasmic $\mathrm{pH}$ homeostasis? Trends Microbiol 2002, 10(2):70-74

20. Stingl K, Uhlemann EM, Schmid R, Altendorf K, Bakker EP: Energetics of Helicobacter pylori and its implications for the mechanism of ureasedependent acid tolerance at pH 1. J Bacteriol 2002, 184(11):3053-3060

21. Coker C, Poore CA, Li X, Mobley HL: Pathogenesis of Proteus mirabilis urinary tract infection. Microbes Infect 2000, 2(12):1497-1505.

22. Dattelbaum JD, Lockatell CV, Johnson DE, Mobley HL: UreR, the transcriptional activator of the Proteus mirabilis urease gene cluster, is required for urease activity and virulence in experimental urinary tract infections. Infect Immun 2003, 71(2):1026-1030.

23. Island MD, Mobley HL: Proteus mirabilis urease: operon fusion and linker insertion analysis of ure gene organization, regulation, and function. $J$ Bacteriol 1995, 177(19):5653-5660

24. Burne RA, Chen YY: Bacterial ureases in infectious diseases. Microbes Infect 2000, 2(5):533-542

25. Sangari FJ, Seoane A, Rodriguez MC, Aguero J, Garcia Lobo JM: Characterization of the urease operon of Brucella abortus and assessment of its role in virulence of the bacterium. Infect Immun 2007, 75(2):774-780

26. Maroncle N, Rich C, Forestier C: The role of Klebsiella pneumoniae urease in intestinal colonization and resistance to gastrointestinal stress. Res Microbiol 2006, 157(2):184-193.

27. Olivera-Severo D, Wassermann GE, Carlini CR: Ureases display biological effects independent of enzymatic activity: is there a connection to diseases caused by urease-producing bacteria? Braz J Med Biol Res 2006, 39(7):851-861

28. Williams CL, Preston T, Hossack M, Slater C, McColl KE: Helicobacter pylori utilises urea for amino acid synthesis. FEMS Immunol Med Microbiol 1996 13(1):87-94.

29. Harris PR, Ernst PB, Kawabata S, Kiyono H, Graham MF, Smith PD: Recombinant Helicobacter pylori urease activates primary mucosal macrophages. J Infect Dis 1998, 178(5):1516-1520.

30. Zhang JY, Liu T, Guo H, Liu XF, Zhuang Y, Yu S, Chen L, Wu C, Zhao Z, Tang B, Luo P, Mao XH, Guo G, Shi Y, Zou QM: Induction of a Th17 cell response by Helicobacter pylori urease subunit B. Immunobiology 2010

31. Tanahashi T, Kita M, Kodama T, Yamaoka Y, Sawai N, Ohno T, Mitsufuji S, Wei YP, Kashima K, Imanishi J: Cytokine expression and production by purified Helicobacter pylori urease in human gastric epithelial cells. Infect Immun 2000, 68(2):664-671.

32. Harris PR, Mobley HL, Perez-Perez Gl, Blaser MJ, Smith PD: Helicobacter pylori urease is a potent stimulus of mononuclear phagocyte activation and inflammatory cytokine production. Gastroenterology 1996, 111(2):419-425.

33. Wroblewski LE, Shen L, Ogden S, Romero-Gallo J, Lapierre LA, Israel DA, Turner JR, Peek RM Jr: Helicobacter pylori dysregulation of gastric epithelial tight junctions by urease-mediated myosin II activation. Gastroenterology 2009, 136(1):236-246.
34. Fan X, Gunasena H, Cheng Z, Espejo R, Crowe SE, Ernst PB, Reyes VE: Helicobacter pylori urease binds to class II MHC on gastric epithelial cells and induces their apoptosis. J Immunol 2000, 165(4):1918-1924.

35. Schwartz JT, Allen LA: Role of urease in megasome formation and Helicobacter pylori survival in macrophages. I Leukoc Biol 2006, 79(6):1214-1225

36. Makristathis A, Rokita E, Labigne A, Willinger B, Rotter ML, Hirschl AM Highly significant role of Helicobacter pylori urease in phagocytosis and production of oxygen metabolites by human granulocytes. J Infect Dis 1998, 177(3):803-806

37. Kuwahara H, Miyamoto Y, Akaike T, Kubota T, Sawa T, Okamoto S, Maeda H: Helicobacter pylori urease suppresses bactericidal activity of peroxynitrite via carbon dioxide production. Infect Immun 2000, 68(8):4378-4383.

38. Rokita E, Makristathis A, Presterl E, Rotter ML, Hirschl AM: Helicobacter pylori urease significantly reduces opsonization by human complement. J Infect Dis 1998, 178(5):1521-1525.

39. Bakaletz LO, Baker BD, Jurcisek JA, Harrison A, Novotny LA, Bookwalter JE, Mungur R, Munson RS Jr: Demonstration of Type IV pilus expression and a twitching phenotype by Haemophilus influenzae. Infect Immun 2005, 73(3):1635-1643

40. Erwin AL, Nelson KL, Mhlanga-Mutangadura T, Bonthuis PJ, Geelhood JL, Morlin G, Unrath WC, Campos J, Crook DW, Farley MM, Henderson FW, Jacobs RF, Muhlemann K, Satola SW, van Alphen L, Golomb M, Smith AL: Characterization of genetic and phenotypic diversity of invasive nontypeable Haemophilus influenzae. Infect Immun 2005, 73(9):5853-5863.

41. Sethi S, Wrona C, Grant BJ, Murphy TF: Strain-specific immune response to Haemophilus influenzae in chronic obstructive pulmonary disease. Am J Respir Crit Care Med 2004, 169:448-453.

42. Adlowitz DG, Kirkham C, Sethi S, Murphy TF: Human serum and mucosal antibody responses to outer membrane protein G1b of Moraxella catarrhalis in chronic obstructive pulmonary disease. FEMS Immunol Med Microbiol 2006, 46(1):139-146.

43. Adlowitz DG, Sethi S, Cullen P, Adler B, Murphy TF: Human antibody response to outer membrane protein G1a, a lipoprotein of Moraxella catarrhalis. Infect Immun 2005, 73(10):6601-6607.

44. LaFontaine ER, Snipes LE, Bullard B, Brauer AL, Sethi S, Murphy TF: Identification of domains of the Hag/MID surface protein recognized by systemic and mucosal antibodies in adults with chronic obstructive pulmonary disease following clearance of Moraxella catarrhalis. Clin Vaccine Immunol 2009, 16(5):653-659.

45. Bosse JT, Maclnnes Jl: Urease activity may contribute to the ability of Actinobacillus pleuropneumoniae to establish infection. Canadian J Vet Res 2000, 64(3):145-150.

46. Kaulbach HC, White MV, Igarashi Y, Hahn BK, Kaliner MA: Estimation of nasal epithelial lining fluid using urea as a marker. Journal Allergy Clin Immunol 1993, 92(3):457-465.

47. Murphy TF, Kirkham C, Sethi S, Lesse AJ: Expression of a peroxiredoxinglutaredoxin by Haemophilus influenzae in biofilms and during human respiratory tract infection. FEMS Immunol Med Microbiol 2005, 44(1):81-89.

48. Ruckdeschel EA, Kirkham C, Lesse AJ, Hu Z, Murphy TF: Mining the Moraxella catarrhalis genome: identification of potential vaccine antigens expressed during human infection. Infect Immun 2008, 76(4):1599-1607.

49. Rudd PT, Cassell GH, Waites KB, Davis JK, Duffy LB: Ureaplasma urealyticum pneumonia: experimental production and demonstration of age-related susceptibility. Infect Immun 1989, 57(3):918-925.

50. Monack DM, Falkow S: Cloning of Bordetella bronchiseptica urease genes and analysis of colonization by a urease-negative mutant strain in a guinea-pig model. Mol Microbiol 1993, 10(3):545-553.

51. Ketterer MR, Shao JQ, Hornick DB, Buscher B, Bandi VK, Apicella MA: Infection of primary human bronchial epithelial cells by Haemophilus influenzae: macropinocytosis as a mechanism of airway epithelial cell entry. Infect Immun 1999, 67:4161-4170.

52. Forsgren J, Samuelson A, Ahlin A, Jonasson J, Rynnel-Dagoo B, Lindberg A: Haemophilus influenzae resides and multiplies intracellularly in human adenoid tissue as demonstrated by in situ hybridization and bacterial viability assay. Infect Immun 1994, 62:673-679.

53. Bandi V, Apicella MA, Mason E, Murphy TF, Siddiqi A, Atmar RL, Greenberg SB: Nontypeable Haemophilus influenzae in the lower respiratory tract of patients with chronic bronchitis. Am J Respir Crit Care Med 2001, 164(11):2114-2119. 
54. Sethi S, Evans N, Grant BJB, Murphy TF: New strains of bacteria and exacerbations of chronic obstructive pulmonary disease. $N$ Engl J Med 2002, 347:465-471.

55. Murphy TF, Brauer AL, Sethi S, Kilian M, Cai X, Lesse AJ: Haemophilus haemolyticus: a human respiratory tract commensal to be distinguished from Haemophilus influenzae. J Infect Dis 2007, 195(1):81-89.

56. Menard R, Sansonetti PJ, Parsot C: Nonpolar mutagenesis of the ipa genes defines IpaB, IpaC, and IpaD as effectors of Shigella flexneri entry into epithelial cells. J Bacteriol 1993, 175(18):5899-5906.

57. Herriott RM, Meyer EY, Vogt M, Modan M: Defined medium for growth of Haemophilus influenzae. J Bacteriol 1970, 101:513-516.

58. Poje G, Redfield RJ: Transformation of Haemophilus influenzae. In Haemophilus influenzae protocols. Edited by: Herbert M, Wood D, Moxon E. Totowa, NJ: Humana Press; 2003:57-70.

59. Murphy TF, Kirkham C, Lesse AJ: Construction of a mutant and characterization of the role of the vaccine antigen P6 in outer membrane integrity of nontypeable Haemophilus influenzae. Infect Immun 2006, 74(9):5169-5176.

60. Senior BW, Bradford NC, Simpson DS: The ureases of Proteus strains in relation to virulence for the urinary tract. J Med Microbiol 1980, 13(4):507-512.

61. American Thoracic Society: Standards for the diagnosis and care of patients with chronic obstructive pulmonary disease. Am J Respir Crit Care Med 1995, $152(5$ Pt 2):S77-S121.

62. Sethi S, Muscarella K, Evans N, Klingman KL, Grant BJB, Murphy TF: Airway inflammation and etiology of acute exacerbations of chronic bronchitis. Chest 2000, 118:1557-1565.

63. Murphy TF, Kirkham C, Liu DF, Sethi S: Human immune response to outer membrane protein $\mathrm{CD}$ of Moraxella catarrhalis in adults with chronic obstructive pulmonary disease. Infect Immun 2003, 71(3):1288-1294.

doi:10.1186/1471-2180-11-183

Cite this article as: Murphy and Brauer: Expression of urease by Haemophilus influenzae during human respiratory tract infection and role in survival in an acid environment. BMC Microbiology 2011 11:183.

\section{Submit your next manuscript to BioMed Central and take full advantage of:}

- Convenient online submission

- Thorough peer review

- No space constraints or color figure charges

- Immediate publication on acceptance

- Inclusion in PubMed, CAS, Scopus and Google Scholar

- Research which is freely available for redistribution

Submit your manuscript at www.biomedcentral.com/submit
Biomed Central 